\title{
CONCEPTUALIZATION OF PEDAGOGICAL ENTREPRENEURSHIP
}

\author{
Agnese Slišāne \\ University of Latvia, Latvia
}

\begin{abstract}
The European Union (EU) and the Organisation for Economic Co-operation and Development (OECD) have stated that education is central to economic and social policy development. Entrepreneurial competence has been topical since 2006, when the European Commission identified a "sense of initiative and entrepreneurship" as one of the eight competencies necessary for all members of a knowledge-based society, however there is still no consensus on what the distinctive elements of entrepreneurship as a competency are.

Latvian educational reforms involve changes in the teacher education system in order to have highly qualified, competent, and excellence-oriented teachers who are able to respond quickly to the demands of the labour market and adapt to technological developments. The school reforms also necessitate teachers to create a study process where students develop entrepreneurial competence, which is a new and still vague concept.

The aim of the research is to conceptualize pedagogical entrepreneurship through a systematic literature review of the term 'pedagogical entrepreneurship' and its components entrepreneurial skills and teachers' entrepreneurial behaviour (the methodological approach to teaching, which characterizes entrepreneurial behaviour in the context of education).

The present research analyzes 35 publications available on Web of Science, Scopus, ScienceDirect, and ResearchGate that were published in English from 2011 to 2021. The result of the systematic literature review is the compilation of literature for the terms 'pedagogical entrepreneurship', 'entrepreneurial skills', and 'teachers' entrepreneurial behaviour' ('teacherpreneurs'), as well as summarized explanations of each term.

The results can be used for further research on pedagogical entrepreneurship and its components. Comprehension of the value of pedagogical entrepreneurship in the context of education will create fertile soil for the effective integration and elaboration of entrepreneurial skills for teacher education students as well as already practising teachers that will support them to implement a competency-based curriculum and be competitive in the changing labour market.
\end{abstract}

Keywords: entrepreneurial behaviour, entrepreneurship education, entrepreneurial skills, entrepreneurial teachers, entrepreneurship competence, pedagogical entrepreneurship, teacherpreneurs. 


\section{Introduction}

The growing interdependence of the world's economies, cultures, and populations has affected the demand and supply of the labour market (World Bank, 2020). This has led to new competencies required to deal with a contemporary situation brought about by globalization. International collaboration and a mixed type of economy require digital solutions and self-directed activity, as well as the ability to plan your time and manage work duties. This has been even more relevant during the pandemic situation, and that is why digital literacy and entrepreneurial skills are the most important skills necessary for the $21^{\text {st }}$-century economic and business environment, which affects a country's economic development (Turulja et al., 2020).

The changing socio-economic situation affects all spheres of life, and today, strategies for entrepreneurship in an educational context are a global phenomenon that emanates from policy. Policy has thus been a significant point of departure for research on entrepreneurship in a pedagogical context (Dal et al., 2016). The European Commission first referred to the importance of entrepreneurship education in 2006 in the Green Paper on Entrepreneurship in Europe, and the improvement of the entrepreneurial capacity of European citizens and organizations has been one of the key policy objectives for the European Union (EU) and Member States for many years (Bacigalupo et al., 2016). Although entrepreneurial capacity building has been on the agenda for many years, there is still no consensus on what the distinctive elements of entrepreneurship as a competency are (Slišāne \& Rubene, 2021).

The Latvian education system has been undergoing changes both in schools and in the development processes of higher education. The task of implementing schools' competency-based curricula is an immediate issue (Regulations on State General Secondary Education Standards and Samples of General Secondary Education Programs, 2019), but its implementation is hampered by the boundaries of the existing teacher education system, established in 2020. As such, there arse plans to strengthen the teacher education system by 2027 to make teacher education better so that it able to respond quickly to labour market demands and adapt to technological developments (Republic of Latvia, 2019).

$21^{\text {st }}$-century teachers are perceived as educational innovators cultivating innovative pedagogy (Howard et al., 2018), and they should be encouraged to foster entrepreneurial skills, competencies, and mindsets. This could also help teachers to develop and implement an entrepreneurial attitude amongst their students from an early age (Arruti \& Paños-Castro, 2020).

Over the years, various studies have used different terms such as 'entrepreneurship education', 'entrepreneurial learning', and 'entrepreneurship 
pedagogy' to describe the link between entrepreneurship and pedagogical practices. As the term 'entrepreneurship' originally derives from the economic sector, it is essential to clarify its meaning in a pedagogical context. A narrow and traditional use of the term 'entrepreneurship' refers almost solely to business, including how people learn to start and operate an enterprise (Dal et al., 2016). A detached and much wider approach to the term is connected to the human qualities and skills that make it possible for individuals within organizations and communities to act flexibly and creatively when meeting rapid social and economic changes (Erkkilä, 2000).

The research problem is a vague and ambiguous comprehension of pedagogical entrepreneurship. There are no common foundations or criteria that indicate what entrepreneurial behaviour is in the context of education and what skills refer to entrepreneurial competencies. Without a conception of pedagogical entrepreneurship and its components (entrepreneurial skills), entrepreneurial methodology teachers have no foundation on which to develop entrepreneurial competencies for their students, which leads to the main problem - they cannot fulfil labour market requirements.

The aim of the research is to conceptualize pedagogical entrepreneurship through a selection and summarization of literature that studies pedagogical entrepreneurship, teachers' entrepreneurial behaviour, entrepreneurial skills, and the methodological approach to teaching that characterize entrepreneurial behaviour in the context of education.

Because the aim of the study was to map the research on pedagogical entrepreneurship with relevance for teacher education, the studies in the selection focused on various forms of secondary education. Studies conducted in other types of educational settings (e. g. at university level) or business-related studies where entrepreneurial skills were researched only in a business environment were omitted. The selection thus consists of research on pedagogical entrepreneurship conducted in contexts relevant for teacher education.

The research questions are: (1) What is pedagogical entrepreneurship? (2) What are entrepreneurial skills? (3) What is entrepreneurial behaviour in the context of education?

\section{Method}

In order to find answers to the above questions, a systematic literature review of 35 literature items in the period from 2011 to 2021 was carried out, comprising 32 scientific articles, two policy documents, and the study EntreComp: The Entrepreneurship Competence Framework. Although the keyword: entrepreneurship education, pedagogy, entrepreneurial skills, 
entrepreneurship competencies, entrepreneurial behaviour, pedagogical entrepreneurship, and teacherpreneurs, generated many hits, most texts were not relevant to this study, and a manual selection was carried out in several steps on the basis of title, abstract and content.

Divergent types of scientific studies were selected - empirical studies, systemic literature reviews, articles from scientific journals, policy documents, and technical reports. The guiding principle for the choice of databases was to ensure that the latest international publications in English were included. The selection thus consists of research on pedagogical entrepreneurship conducted in contexts relevant for teacher education.

The present research analyzes only full articles available on Web of Science, Scopus, ScienceDirect, and ResearchGate that were published in English between 2011 and 2021. Initial keywords were identified on the basis of the researchers' knowledge of the field.

The analysis was executed in two stages. First, each of the individual articles was analyzed according to the three research questions - what skills characterize entrepreneurship? What is entrepreneurial behaviour in the context of education? What activities indicate the implementation of pedagogical entrepreneurship? In the second stage, articles were categorized according to their responses to these questions. The results for each question were summarized in a table to get an overview of the publications written in English in the period from 2011 to 2021 that are relevant to pedagogical entrepreneurship.

\section{Results}

As a result of the research, authors and publications were compiled into three sections - pedagogical entrepreneurship, entrepreneurial skills, and teacherpreneurs (entrepreneurship behaviour in the context of education). Each section has a concise summary of the literature items contained within them.

\section{Pedagogical entrepreneurship}

In the process of researching the definition of pedagogical entrepreneurship, nine literature items from 2015-2021 were selected (Table 1). It can be noticed that mostly Nordic countries use the term 'pedagogical entrepreneurship' to define the phenomenon of entrepreneurship's integration into the learning and teaching process. However, both Nordic and European forums maintain that entrepreneurship in education is more than just a relationship between school and business; it is also related to political awareness, cultural life, and family and societal participation (Haara et al., 2016). 
Table 1. Literature about pedagogical entrepreneurship (2015-2021)

\begin{tabular}{|c|c|c|c|}
\hline No. & Author(s) & Publication & Year \\
\hline 1 & Katariina Peltonen & $\begin{array}{l}\text { How can teachers' entrepreneurial } \\
\text { competences be developed? A collaborative } \\
\text { learning perspective }\end{array}$ & 2015 \\
\hline 2 & $\begin{array}{l}\text { Michael Dal, Janne } \\
\text { Elo, Eva Leffler, } \\
\text { Gudrun Svedberg, Mats } \\
\text { Westerberg }\end{array}$ & $\begin{array}{l}\text { Research on pedagogical } \\
\text { entrepreneurship - a literature review } \\
\text { based on studies from Finland, Iceland and } \\
\text { Sweden }\end{array}$ & 2016 \\
\hline 3 & $\begin{array}{l}\text { Frode Olav Haara, } \\
\text { Eirik Jenssen, Ingrid } \\
\text { Fossøy, Inger Karin Røe } \\
\varnothing \text { degărd } \\
\end{array}$ & $\begin{array}{l}\text { The ambiguity of pedagogical } \\
\text { entrepreneurship - the state of the art and } \\
\text { its challenges. }\end{array}$ & 2016 \\
\hline 4 & $\begin{array}{l}\text { Frode Olav Haara, Eirik } \\
\text { Jenssen }\end{array}$ & $\begin{array}{l}\text { Pedagogical entrepreneurship in teacher } \\
\text { education - what and why? }\end{array}$ & 2016 \\
\hline 5 & $\begin{array}{l}\text { Olivier Toutain, Janice } \\
\text { Byrne, Janice Byrne, } \\
\text { Fayolle Alain } \\
\end{array}$ & $\begin{array}{l}\text { Labour market uncertainty and } \\
\text { career perspectives: Competence in } \\
\text { entrepreneurship courses }\end{array}$ & 2017 \\
\hline 6 & $\begin{array}{l}\text { Kevin Celuch, Bryan } \\
\text { Bourdeau, Doan Winkel }\end{array}$ & $\begin{array}{l}\text { Entrepreneurial identity: The missing link } \\
\text { for entrepreneurship education }\end{array}$ & 2017 \\
\hline 7 & $\begin{array}{l}\text { Annafatmawaty B. T. } \\
\text { Ismail, Sukanlaya } \\
\text { Sawang, Roxanne Zolin }\end{array}$ & $\begin{array}{l}\text { Entrepreneurship education pedagogy: } \\
\text { Teacher-student-centred paradox }\end{array}$ & 2018 \\
\hline 8 & Adri Du Toit & $\begin{array}{l}\text { Constructive congruencies in self-directed } \\
\text { learning and entrepreneurship education }\end{array}$ & 2019 \\
\hline 9 & $\begin{array}{l}\text { Agnese Slišāne, Zanda } \\
\text { Rubene }\end{array}$ & $\begin{array}{l}\text { Entrepreneurship Pedagogy: } \\
\text { Entrepreneurial Skills and Mindset? }\end{array}$ & 2021 \\
\hline
\end{tabular}

Pedagogical entrepreneurship blends two subjects, each with its own traditions and way of thinking: on the one hand, pedagogy, with its ancient scientific traditions focused on socialization, knowledge, motivation, learning, and creation, and, on the other hand, entrepreneurship, which is rooted in an economic tradition focused on business development, individual initiative, and risk-taking. However, pedagogical entrepreneurship should not be about supporting or opposing economics and business, but about paving the way for human development and growth through an emphasis on authenticity, action competence, and students' ability to self-regulate (Haara \& Jenssen, 2016).

It is valuable to understand pedagogical entrepreneurship to consider the necessity of its development for educators, and a systematic review of the impact of entrepreneurship education in higher education shows that there are several benefits for students. For instance, it will help an individual to effect personal change (in attitude, knowledge, skills, feasibility, and entrepreneurial intention), help them with business start-ups (Ismail et al., 2018), 
provide an opportunity for them to establish non-traditional learning spaces, facilitate a creative atmosphere, and encourage cooperation among students (Dal at al., 2016).

Pedagogical entrepreneurship concerns how teachers can use their own entrepreneurial competence to manage their professional life outside as well as inside the classroom. Teachers and pedagogy play key roles in developing students' entrepreneurial competence. In order to achieve the goal of entrepreneurial education - that is, to develop the learner's entrepreneurial mindset and competence -, learners must be included in the learning process (Toutain \& Fayolle, 2017; Slišāne \& Rubene, 2021).

\section{Entrepreneurial skills}

Contrary to pedagogical entrepreneurship, the term 'entrepreneurial skill' is more commonly used in the context of education since the (EU) emphasizes the need to move towards competence-based education (Council of the European Union, 2018). After the evaluation and selection of the literature, eight items on entrepreneurial skill from 2016-2020 were chosen (Table 2).

Table 2. Literature about entrepreneurial skills (2016-2019)

\begin{tabular}{|l|l|l|l|}
\hline No. & Author(s) & Publication & Year \\
\hline 1 & $\begin{array}{l}\text { Margherita Bacigalupo, } \\
\text { Panagiotis Kampylis, } \\
\text { Yves Punie, Godelieve } \\
\text { Van Den Brande }\end{array}$ & $\begin{array}{l}\text { EntreComp: The Entrepreneurship Competence } \\
\text { Framework. Luxembourg: Publications Office } \\
\text { of the European Union. }\end{array}$ & 2016 \\
\hline 2 & $\begin{array}{l}\text { Frode Olav Haara, } \\
\text { Eirik Jenssen }\end{array}$ & $\begin{array}{l}\text { Pedagogical entrepreneurship in teacher } \\
\text { education - what and why? }\end{array}$ & 2016 \\
\hline 3 & $\begin{array}{l}\text { Ramona Diana Leon } \\
\text { Developing Entrepreneurial Skills. An } \\
\text { Educational and Intercultural Perspective. }\end{array}$ & 2017 \\
\hline 4 & $\begin{array}{l}\text { Organisation for } \\
\text { Economic Co-operation } \\
\text { and Development }\end{array}$ & $\begin{array}{l}\text { Developing Entrepreneurship Competencies. } \\
\text { SME Ministerial Conference. OECD. }\end{array}$ & 2018 \\
\hline 5 & $\begin{array}{l}\text { Anderson Galvão, } \\
\text { Joao J. Ferreira, Carla } \\
\text { Marques }\end{array}$ & $\begin{array}{l}\text { Entrepreneurship education and training } \\
\text { as facilitators of regional development: } \\
\text { a systematic literature review }\end{array}$ & 2018 \\
\hline 6 & $\begin{array}{l}\text { Organisation for } \\
\text { Economic Co-operation } \\
\text { and Development }\end{array}$ & $\begin{array}{l}\text { SME Policy Index: ASEAN 2018: Boosting } \\
\text { Competitiveness and Inclusive Growth. OECD/ } \\
\text { Economic Research Institute for ASEAN and } \\
\text { East Asia. }\end{array}$ & 2018 \\
\hline 7 & $\begin{array}{l}\text { Economic Research } \\
\text { Institute for ASEAN } \\
\text { of pre-service elementary teachers on } \\
\text { professional education program through } \\
\text { the skills of disruptive innovators }\end{array}$ & $\begin{array}{l}\text { Combination of Innovation education and pro- } \\
\text { fessional education in colleges and universities }\end{array}$ & 2019 \\
\hline 8 & $\begin{array}{l}\text { Jingyi Zhao } \\
\text { andoving the entrepreneurship competence }\end{array}$ & 2019 \\
\hline
\end{tabular}


The European Commission first referred to the importance of entrepreneurship education in the Green Paper on Entrepreneurship in Europe in 2003 (Bacigalupo et al., 2016). The development of the entrepreneurial capacity of European citizens and organizations has been one of the key policy objectives for the EU and Member States for many years. There is a growing awareness that entrepreneurial skills, knowledge, and attitudes can be learned and, in turn, lead to the widespread development of entrepreneurial mindsets and culture, which will benefit both individuals and society (Bacigalupo et al., 2016).

According to the Organisation for Economic Co-operation and Development's (OECD) publication Developing Entrepreneurship Competencies, entrepreneurial competencies include creativity, problem-solving skills, initiative, the ability to combine resources, and financial and technological knowledge (OECD, 2018). There is a core set of entrepreneurial competencies that allow individuals to identify, create, and respond to opportunities to create value by pooling resources and demonstrating self-efficacy, confidence, and a determination to overcome obstacles. One of the goals of developing entrepreneurial competence is to reduce the fear of failure by raising awareness and providing the knowledge and skills necessary to help individuals deal with problem situations/obstacles (OECD, 2018).

According to Leon (2017), entrepreneurial skills are multidimensional and combine knowledge, behaviour, and attitudes. They are a complex blend of rational, emotional, and spiritual knowledge. Any combination that promotes innovation and value creation can be referred to as "entrepreneurial skills" (Leon, 2017).

Entrepreneurial skills can be summarized as consisting of action orientation, creativity, initiative, risk-taking, perseverance, leadership, communication skills, problem-solving skills, the ability to collaborate/work in a team, the ability to learn, and time management.

\section{Entrepreneurial behaviour in the context of education}

To answer the question of what entrepreneurial behaviour in the context of education can be seen in methodological approaches to teaching, the most relevant 18 literature items from 2011-2020 were selected. In the process of the research, the terms 'entrepreneurial teachers' and 'teacherpreneurs' refered to the teachers who are implementing actions with entrepreneurial characteristics during their teaching.

Teachers who have entrepreneurial skills demonstrate entrepreneurial behaviour that improves their own performance and creates better conditions for students to learn. Entrepreneurial behaviour is defined as behaviour that involves recognizing opportunities and marshalling resources to take advantage of and act upon these opportunities. It also includes 
the ability to pursue innovative ideas effectively, motivate students to think critically and creatively, constantly search for new developments in the field of education, create compelling technology-based projects inside and outside the classroom, and find the necessary resources to introduce to learners that help them to adapt curricula and teaching materials to changes in a fast-changing environment (Neto et al., 2017; Khorrami et al., 2018), which contributes to the relevance of teaching materials. All this contributes to the academic success of the students of these teachers (Turulja et al., 2020).

The study carried out by Keyhani and Kim (2020) concluded that entrepreneurial teachers are socially motivated, innovative, collaborative, proactive, opportunity-minded, fully present in their work, knowledgeable, dedicated, resourceful, risk-tolerant, visionary and self-improvement-oriented. These traits help them to develop an entrepreneurial environment where learners' initiative, ideas, experimentation, individual and collaborative self-guided participation, and connection between their life outside of school and the contents and methods to be learned in school are implemented (Hietanen, 2014).

From the literature review, it can be concluded that teacherpreneurs have skills such as flexibility, problem-solving, the ability to recognize opportunities and marshal financial as well as human recourses, creativity, and vision. They demonstrate initiative, create new teaching methods, broaden students' view and learning experience by collaborating inside and outside school activities, provide opportunities for students to develop and use their ideas, and integrate activities that reflect novel teaching methods with activities that broaden the learning possibilities of students.

Table 3. Literature about entrepreneurial behaviour in the context of education (2011-2020)

\begin{tabular}{|l|l|l|l|}
\hline No & Author(s) & Publication & Year \\
\hline 1 & $\begin{array}{l}\text { Ana Pérez - Luñoa, } \\
\text { Johan Wiklund, Ramón } \\
\text { Valle Cabrera }\end{array}$ & $\begin{array}{l}\text { The dual nature of innovative activity: } \\
\text { How entrepreneurial orientation influences } \\
\text { innovation generation and adoption }\end{array}$ & 2011 \\
\hline 2 & $\begin{array}{l}\text { Martin Obschonka, } \\
\text { Rainer K Silbereisen, } \\
\text { Eva Schmitt } \\
\text {-Rodermund }\end{array}$ & $\begin{array}{l}\text { Explaining entrepreneurial behavior: } \\
\text { Dispositional personality traits, growth of } \\
\text { personal entrepreneurial resources, and } \\
\text { business idea generation }\end{array}$ & 2012 \\
\hline 3 & Lenita Hietanen & $\begin{array}{l}\text { Developing Entrepreneurial Learning } \\
\text { Environments in Finnish General Education }\end{array}$ & 2014 \\
\hline 4 & $\begin{array}{l}\text { Council of the European } \\
\text { Union }\end{array}$ & $\begin{array}{l}\text { Council conclusions on entrepreneurship in } \\
\text { education and training }\end{array}$ & 2015 \\
\hline 5 & William Walton Kirkley & Entrepreneurial behaviour: the role of values & 2016 \\
\hline
\end{tabular}




\begin{tabular}{|c|c|c|c|}
\hline No & Author(s) & Publication & Year \\
\hline 6 & $\begin{array}{l}\text { Roque do Carmo } \\
\text { Amorim Neto, Vinícius } \\
\text { Picanço Rodrigues, } \\
\text { Shannon Panzer } \\
\end{array}$ & $\begin{array}{l}\text { Exploring the relationship between } \\
\text { entrepreneurial behavior and teachers' job } \\
\text { satisfaction }\end{array}$ & 2017 \\
\hline 7 & $\begin{array}{l}\text { The United Nations } \\
\text { Educational, Scientific } \\
\text { and Cultural } \\
\text { Organization }\end{array}$ & Education and Skills for the $21^{\text {st }}$ Century & 2017 \\
\hline 8 & $\begin{array}{l}\text { Patrick Howard, Charity } \\
\text { Becker, Sean Wiebe, } \\
\text { Mindy Carter, Peter } \\
\text { Gouzouasis, Mitchell } \\
\text { McLarnon, Pamela } \\
\text { Richardson, Kathryn } \\
\text { Ricketts, Layal Schuman } \\
\end{array}$ & $\begin{array}{l}\text { Creativity and pedagogical innovation: } \\
\text { Exploring teachers' experiences of risk- } \\
\text { taking }\end{array}$ & 2018 \\
\hline 9 & $\begin{array}{l}\text { Mina Khorrami, } \\
\text { Homayon Farhadian, } \\
\text { Enayat Abbasi }\end{array}$ & $\begin{array}{l}\text { Determinant competencies for emerging } \\
\text { educators' entrepreneurial behavior in the } \\
\text { Institute of Agricultural Applied- Scientific } \\
\text { Education, Iran }\end{array}$ & 2018 \\
\hline 10 & $\begin{array}{l}\text { Yue Peng, Jamie S. } \\
\text { Pyper }\end{array}$ & $\begin{array}{l}\text { Finding success with pedagogical } \\
\text { innovation: A case from CSL teachers' } \\
\text { experiences with TBLT }\end{array}$ & 2019 \\
\hline 11 & $\begin{array}{l}\text { Nadine Blankvoort, } \\
\text { Vera C. Kaelin, Soemitro } \\
\text { Poerbodipoero, Susanne } \\
\text { Guidetti }\end{array}$ & $\begin{array}{l}\text { Higher education students' experiences } \\
\text { of a short-term international programme: } \\
\text { exploring cultural competency and } \\
\text { professional development }\end{array}$ & 2019 \\
\hline 12 & $\begin{array}{l}\text { Roque do Carmo } \\
\text { Amorim Neto, Vinícius } \\
\text { Picanço Rodrigues, } \\
\text { Kathryn Campbell, } \\
\text { Meaghan Polega, Torrie } \\
\text { Ochsankehl } \\
\end{array}$ & $\begin{array}{l}\text { Teamwork and Entrepreneurial Behavior } \\
\text { among K-12 Teachers in the United States }\end{array}$ & 2020 \\
\hline 13 & $\begin{array}{l}\text { Saeid Karimi, Ahmad } \\
\text { Salman Makreet }\end{array}$ & $\begin{array}{l}\text { The Role of Personal Values in Forming } \\
\text { Students' Entrepreneurial Intentions in } \\
\text { Developing Countries }\end{array}$ & 2020 \\
\hline 14 & $\begin{array}{l}\text { Lejla Turulja, Amra } \\
\text { Kapo, Kemal Kacapor, } \\
\text { Nijaz Bajgoric }\end{array}$ & $\begin{array}{l}\text { Teachers' digital competence enhancing } \\
\text { high school students' success: the mediating } \\
\text { role of pedagogical innovation and } \\
\text { entrepreneurship in teaching }\end{array}$ & 2020 \\
\hline 15 & $\begin{array}{l}\text { Arantza Arruti, Jessica } \\
\text { Paños-Castro }\end{array}$ & $\begin{array}{l}\text { International entrepreneurship education for } \\
\text { pre-service teachers: a longitudinal study }\end{array}$ & 2020 \\
\hline 16 & $\begin{array}{l}\text { Najmeh Keyhani, Mi } \\
\text { Song Kim }\end{array}$ & $\begin{array}{l}\text { A Systematic Literature Review of Teacher } \\
\text { Entrepreneurship }\end{array}$ & 2020 \\
\hline 17 & European Commission & Erasmus + Programme Guide & 2020 \\
\hline 18 & Najmeh Keyhani & $\begin{array}{l}\text { Entrepreneurial Teachers: The Novice and } \\
\text { the Experienced }\end{array}$ & 2020 \\
\hline
\end{tabular}




\section{Discussion}

Studies and recommendations from the OECD and European Commission show that entrepreneurial competency must be developed in the learning process to attain success in one's personal life as well as professional field. However, it still can be seen that entrepreneurial skills are analyzed more in the business context rather than the educational context, which shows the deeply rooted assumption that entrepreneurial skills are needed only for entrepreneurs.

Although the term 'pedagogical entrepreneurship' is still vague and ambiguous, the belief that entrepreneurial competencies and knowledge are developed over time in society and through education is a strong foundation for conducting research on methods to improve the learning environment, methodology, materials, student involvement, internationalization, collaboration, digitalization, and systematic overview of education's ability to adapt to changes in the global economic situation.

After the conceptualization of pedagogical entrepreneurship and its components, observations of the current situation - future and practising teachers' knowledge, attitudes, and entrepreneurial skills in the context of education - would be a valuable basis for the creation of a unified support system for every educator, providing courses and methodology to habitualize pedagogical entrepreneurship in one's personal and professional life. Further, the evaluation of methods for the development of pedagogical entrepreneurship and understanding the impact of each method on the development of entrepreneurial skills are necessary to create the most effective set of methods.

\section{Conclusions}

- Although entrepreneurial competencies in the context of education have mostly arisen from the political interest in overcoming cycles of economic activity and are based on the need to stimulate the economy and prosperity, they have a positive impact on individuals' personal and professional growth.

- There is a growing awareness that entrepreneurial skills, knowledge, and attitudes can be learned and in turn lead to the widespread development of entrepreneurial mindsets and culture, which will benefit individuals and society as a whole.

- Problem-solving, practice-based and real tasks, the ability to search for solutions independently, reflection, authentic knowledge transfer, and the development of an understanding of the market must all be used to develop entrepreneurial skills in the learning process. 
- Entrepreneurial skills are a set of tools that can be advanced over time during study and practice. These skills allow individuals to identify their strengths and respond to opportunities, create value by pooling resources, and demonstrate self-efficacy, confidence, and a determination to overcome obstacles. Entrepreneurial skills raise awareness and provide the knowledge and skills necessary to help individuals deal with problem situations.

- Pedagogical entrepreneurship is carried out by teacherpreneurs who are innovative, flexible, solve problems when they see one, know how to arrange resources and work in a team, creative, and visionary. They construct new teaching methods and collaborate with partners both inside and outside the school environment. They also motivate and support students to develop and use their ideas.

- Pedagogical entrepreneurship creates a positive setting for innovation and creativity in teaching that promotes better academic success for the students.

- Teachers and pedagogy play key roles in developing students' entrepreneurial competence. To achieve the goals of competency-based education, teacher education students (future teachers) need to develop their entrepreneurial skills and understand how these skills can be transferred through their performance to their students. To achieve that, a common understanding of pedagogical entrepreneurship and its components must be demonstrated, and a methodology for its implementation must also be established.

- To foster and flourish, pedagogical entrepreneurship's purpose and longterm advantages must be comprehended to obtain support from those who will bring this approach to life - the educators of teachers and teacher education students.

\section{Acknowledgment}

This research was supported by the project "Assessment of Competences of Higher Education Students and Dynamics of Their Development in the Study Process" (ESF project 8.3.6.2: "Development and Implementation of the Education Quality Monitoring System" project agreement number 8.3.6.2/17/I/001(23-12.3e/19/103)).

\section{References}

Arruti, A., \& Paños-Castro, J. (2020). International entrepreneurship education for preservice teachers: a longitudinal study. Education + Training, 62(7/8), 825-841. https:// doi.org/10.1108/ET-04-2020-0098 
Bacigalupo, M. K., Kampylis, P., Punie, Y., \& van den Brande, G. (2016). EntreComp: The Entrepreneurship Competence Framework. Publications Office of the European Union.

Council of the European Union. (2018). Council recommendation of 22 May 2018 on key competences for lifelong learning. https://eur-lex.europa.eu/legal-content/EN/ TXT/?uri = uriserv:OJ.C_.2018.189.01.0001.01.ENG\&toc $=$ OJ:C:2018:189:TOC.

Dal, M., Elo, J., Leffler, E., Svedberg, G., \& Westerberg, M. (2016). Research on pedagogical entrepreneurship - a literature review based on studies from Finland, Iceland and Sweden. Education Inquiry, 7(2), 159-182. doi:10.3402/edui.v7.30036

Erkkilä, K. (2000). Entrepreneurial Education: Mapping the Debates in the United States, the United Kingdom and Finland. Garland Publishing Inc.

Haara, F. O., \& Jenssen, E. S. (2016). Pedagogical entrepreneurship in teacher education - what and why? Tímarit um uppeldi og menntun / Icelandic Journal of Education, 25(2), 183-196.

Haara, F. O., Jenssen, E. S., Fossøy, I., \& Røe Ødegård, I. K. (2016). The ambiguity of pedagogical entrepreneurship - the state of the art and its challenges. Education Inquiry, 7(2), 29912. doi:10.3402/edui.v7.29912

Hietanen, L. (2014, November). Developing Entrepreneurial Learning Environments in Finnish General Education. Paper presented at the ISBE Conference, Manchester.

Howard, P., Becker, C., Wiebe, S., Carter, M., Gouzouasis, P., McLarnon, M., Richardson, P., Ricketts, K., \& Schuman, L. (2018). Creativity and pedagogical innovation: Exploring teachers' experiences of risk-taking. Journal of Curriculum Studies, 50(6), 850-864. https://doi.org/10.1080/00220272.2018.1479451

Ismail, A. B. T., Sawang, S., \& Zolin, R. (2018). Entrepreneurship education pedagogy: teacher-student-centred paradox. Education and Training, 60(2), 168-184. https://doi. org/10.1108/ET-07-2017-0106

Keyhani, N. \& Kim, M. S. (2020). A systematic literature review of teacher entrepreneurship. Entrepreneurship Education and Pedagogy. https://doi.org/10.1177\%2F 2515127420917355

Khorrami, H. F. M., Farhadian, H., \& Abbasi, E. (2018). Determinant competencies for emerging educators' entrepreneurial behavior in the Institute of Agricultural Applied Scientific Education, Iran. Journal of GlobalEntrepreneurship Research, 8(1). https://doi.org/ 10.1186/s40497-018-0096-4

Leon, R. D. (2017). Developing Entrepreneurial Skills. An Educational and Intercultural Perspective. Journal of Entrepreneurship.Management and Innovation, 13(4), 97-121.

Neto, R. do C. A., Picanço Rodrigues, V. \& Panzer, S. (2017). Exploring the relationship between entrepreneurial behavior and teachers' job satisfaction. Teaching and Teacher Education, 63, 254-262. https://doi.org/10.1016/j.tate.2017.01.001

OECD. (2018). Developing Entrepreneurship Competencies. SME Ministerial Conference.

Regulations on State General Secondary Education Standards and Samples of General Secondary Education Programs, 2019/197.6, C - 5.2. (2019). Retrieved from: https:// likumi.lv/ta/id/309597

Slišāne,A., \& Rubene, Z. (2021). Entrepreneurship Pedagogy: Entrepreneurial Skills and Mindset? International Journal of Smart Education and Urban Society, 12(2), 60-71.

Toutain, O., \& Fayolle, A. (2017). Labour market uncertainty and career perspectives: Competence in entrepreneurship courses. In M. Mulder (Ed.), Competence-based Vocational and Professional Education Bridging the Worlds of Work and Education (Technical 
and Vocational Education and Training: Issues, Concerns and Prospects 23) (pp. 985-1006). Springer.

Turulja, L., Kapo, A., Kačapor, K., \& Bajgorić, N. (2020). Teachers' digital competence enhancing high school students' success: the mediating role of pedagogical innovation and entrepreneurship in teaching. 14th International Technology, Education and Development Conference, Valencia, Spain. doi:10.21125/inted.2020.1549

World Bank. (2020). Latvia: Unemployment rate. Retrieved 15.05.2021, from: https:// www.theglobaleconomy.com/Latvia/unemployment_rate/ 